\title{
Bioassessment of Kordan Stream (Iran) Water Quality Using Macro-Zoobenthos Indices
}

\author{
Rezvan Mousavi Nadushan (Corresponding Author) \\ Department of Fishery, Marine Science and Technology Campus \\ North branch of Tehran, Islamic Azad University, Zaaferaniye, Tehran, Iran \\ E-mail: mousavi_naduhan@yahoo.com \\ Mehrazad Ramezani \\ Department of Fishery, Science and Research Campus \\ Islamic Azad University, Hesarak, Tehran, Iran \\ Tel: 009-821-2254-5236Ｅ-mail: mehrazad.ramezani@gmail.com
}

Received: December 21, 2010 Accepted: January 07, 2011 doi:10.5539/ijb.v3n2p127

\begin{abstract}
Changes in water and habitat quality of Kordan Stream were examined using community structure and biotic indices at 3 sites during 2008-2009. This investigation resulted in inventories of benthic insect communities being obtained from this stream. It also resulted in two metrics being calculated from benthic insect communities. Of the metrics used, one indicated EPT taxa richness and one involved a biotic index, HFBI, for organic pollution. Water temperature, water velocity, water depth, dissolved oxygen, BOD5, pH, specific conductivity; phosphate and nitrate concentrations were within ranges usually capable of supporting a diverse biota. Samples were dominated by insects and yielded 142 macroinvertebrate taxa. The scores calculated for HFBI was lowest (4.67) and rated good water quality (some organic pollution probable) at site 1 and increased to 5.45 rated fair (fairly substantial pollution likely) at site 3. EPT ratings were "under a little perturbation" at three sites, suggesting high taxa richness and habitat quality in Kordan Stream.
\end{abstract}

Keywords: Kordan Stream, Macrobenthose, Water quality, HFBI, EPT richness

\section{Introduction}

Running waters are amongst the most threatened ecosystems in the world (Allan and Flecker, 1993). Streams are usually highly variable environments that harbor diverse and unique biota (Malmqvist and Hoffsten, 2000). Anthropogenic activities have strong effects on aquatic ecosystems leading to widespread modification of the physical habitat and consequently of biotic communities and ecological functioning (Principle, 2007). Therefore, river or stream restoration requires an understanding of the structure and function of stream corridor ecosystems and the physical, chemical and biological processes that shape them (USDA, 2000; Hu, 2006).

To assess the quality of running waters, chemical analyses alone are inadequate (Karr and Chu, 1999). In many regions aquatic resources have been degraded because of non point source pollution and alterations of stream channels, riparian areas and entire stream catchments (Fore et al., 1996; Griffith, 2002). Furthermore biological monitoring using macroinvertebrates assemblage can give an indication of past as well as present conditions (Fenoglio, 2002). In addition, biological monitoring is valuable for determining natural and anthropogenic influences on river resources because biota integratively respond to stress from multiple spatial or time scales and several pathways including habitat and water chemistry (Karr, 1981; Ohio EPA, 1987; Rosenberg \& Resh, 1993; Weigel and Robertson, 2007).

Macroinvertebrate responses (e.g., absence or presence, number of individuals, deformities, etc.) reflect short and long term environmental conditions within their native watershed (Suozzo 2006), and reflect intermittent discharges and the synergistic effects of in-stream chemical contaminants often too dilute to detect (Bode et al. 1991; Suozzo, 2006). Recently many techniques, protocols, and indices have been developed to monitor stream quality using changes in taxa composition, diversity and functional organization of aquatic insects (Hilsenhoff, 
1988; Plafkin et al. 1989; Shieh, 2000). Such Rapid Bioassessment Protocols (RBPS) developed by Barbour et al. (U.S. EPA 1999), have greatly increased the assessment efficiency and effectiveness of these surveys. RBPS can reflect overall ecological integrity and directly assess the status of a water body $(\mathrm{Hu}, 2006)$.

The objectives of this study were to collect synoptic water quality information (i.e., temperature, dissolved oxygen, $\mathrm{pH}$, conductivity, turbidity, and discharge), to determine the taxonomic composition and relative abundance of macroinvertebrate community, water quality assessment using HFBI and finally using overall macrobenthose diversity and EPT taxa richness to evaluate the stream health.

\subsection{Study area}

Kordan stream is located in north of Karaj city, $40 \mathrm{~km}$ west of Tehran $\left(50^{\circ} 50^{\prime}\right.$ to $50^{\circ} 55 \mathrm{~N}, 35^{\circ} 55^{\prime}$ to $36^{\circ} 05^{\prime}$ E) with an elevation of $1408 \mathrm{~m}$ in Alborz mountains ecoregion. The stream is about $75 \mathrm{~km}$ long and has a drainage area of $1100 \mathrm{~km}^{2}$ (Figure 1).

The stream basin has annual precipitation of about $650 \mathrm{~mm}$ with the highest precipitation in April and the lowest in September. Local air temperatures historically vary between -6 and $29^{\circ} \mathrm{C}$. Climatic condition is moderate with cold winters and without severe drought in the summers. A part of the river basin has been developed for agricultural purposes and rainbow trout culture. Water from the stream is diverted for irrigation throughout the summer. Furthermore, this area is profitable for producing fruits, nuts (e.g., walnut) and fish, but is a recreational area as well. During the summer, the water quality of river is adversely affected due to release of effluent and garbage from human settlement and also the increase in tourism activities.

\section{Materials and Methods}

An annual study of macroinvertebrates in Kordan stream was conducted for the first time. A surber sampler (area $=30 \times 30 \mathrm{~cm}^{2}$, mesh size $=250 \mu \mathrm{m}$ ) was used to collect 3 samples of benthic aquatic insects at each sampling site monthly from February 2008 to January 2009 (Figure 1). Three replicates were taken from different subsites, two near the banks and one in the centre to cover all different microhabitats (pools and riffles).

Qualitative collections were also made by examining rocks, wood debris, leaf debris, and other microhabitats by hand at each sampling site. All invertebrate collections were preserved in $4 \%$ formaldehyde in the field and then taken to the laboratory for further sorting, identification, and enumeration.

Aquatic insects were identified to family level (and genus when possible), except nymphs of chironomids, which were identified to tribe or subfamily. Specimens were identified to family or genus level mainly according to the Aquatic Entomology (McCafferty, 1981) and Aquatic insects of North Europe (Nelson, 1997).

Physicochemical conditions prevailing at each station were also measured during each collection period. These parameters included water temperature, dissolved oxygen concentration and biochemical oxygen demand (Winkler method), $\mathrm{pH}$ (Aqua Merck. D6100, pH meter), and specific conductance (HORIBA E5-14E conductivity meter). Stream velocity was determined using a Sensa Z300 OTT, and stream depth was recorded using a secchi tube depth. Measures for nitrate and phosphate were determined for the water samples from each site, using the procedures by Greenberg et al. (1992).

Effects of all environmental variables on macroinvertebrate abundances were evaluated using correlation and differences in the number of individuals, number of taxa and biotic indices scores between the sites were analyzed using One-Way ANOVA. Water quality was analyzed using Family level Biotic Index Score System developed by Hilsenhoff (1988) and EPT Taxa Richness (Ephemeroptera, Plecoptera and Trichoptera) was based on Davis and Simon (1995).

\section{Result}

\subsection{Physico - Chemical Characteristics of the area}

Ranges of the physicochemical and hydrological parameters in Kordan Stream are listed in Table 1 and 2. Mean water velocity was $116 \mathrm{~cm} \cdot \mathrm{s}^{-1}$ in Kordan stream with a minimum of $110 \mathrm{~cm} \cdot \mathrm{s}^{-1}$ in August and a maximum of 126 $\mathrm{cm} . \mathrm{s}^{-1}$ in April. Water depth rarely exceeded $75 \mathrm{~cm}$.

The minimum and maximum water temperature recorded was $4^{\circ} \mathrm{C}$ during January and $18.7^{\circ} \mathrm{C}$ during July respectively, with an average of $11.52{ }^{\circ} \mathrm{C}$. Minimum dissolved oxygen concentration, $9.3 \mathrm{mg} .1^{-1}$, was recorded during July and maximum dissolved oxygen concentration, $11.9 \mathrm{mg} \cdot \mathrm{l}^{-1}$ occurred during January. Dissolved oxygen values were above saturation and $\mathrm{BOD}_{5}$ was low at all times at all sites. The differences in dissolved oxygen concentrations and $\mathrm{BOD}_{5}$ between the stations were not significant $(\mathrm{p}>0.05)$. 
The EC values were between 256 and $417 \mu \mathrm{s} / \mathrm{cm}$ with a maximum in the low-water period and minimum in the high-water period. EC values increased from $313 \mu \mathrm{s.cm}$ at site 1 (Aghasht) to $347 \mu \mathrm{s.cm}{ }^{-1}$ at site 3 (downstream) due to the effect of waste water discharge from villages and polluted water from agricultural areas. The amount of $\mathrm{NO}_{3}-\mathrm{N}$ ranged from $0.26 \mathrm{mg} . \mathrm{l}^{-1}$ to $0.56 \mathrm{mg} . \mathrm{l}^{-1}$ and $\mathrm{PO}_{4} \mathrm{P}$ ranged from $0.011 \mathrm{mg} . \mathrm{l}^{-1}$ to $0.027 \mathrm{mg} . \mathrm{l}^{-1}$ during the study period. The $\mathrm{PO}_{4}-\mathrm{P}$ values were generally low at all sites. $\mathrm{NO}_{3}-\mathrm{N}$ and $\mathrm{PO}_{4}-\mathrm{P}$ concentrations increased from upstream sites toward downstream. The use of agricultural fertilizers and urban sewage are believed to increase the Nitrate Nitrogen.

\subsection{Macroinvertebrate community}

A total of 34500 individuals representing 142 taxa, 4 phyla, 9 classes, 21 orders, 56 families, 11 subfamilies, 1 tribe, and 38 genera were identified throughout the year and during this study (Table 3 ).

In terms of both number of individuals, and number of taxa, 10 orders, 42 families, insects were dominant. Dipterans with 13 families, 7 subfamilies, 1 tribe, 9 genus, coleopteran insects with 7 families, 5 genus, and Plecoptera, Ephemeroptera, Trichoptera each one with 5 families, were present at all stations during most collections. During the study period, richness was lowest in May 2007 with 25 taxa and the highest in March and October 2007 with 104 taxa. From a total of 142 taxa, 121 (8 classes, 20 orders, 48 families, 10 subfamilies, 1 tribe, 34 genus) were found in site 1 (Aghasht, one of the upstream tributaries), 112 (6 classes, 16 orders, 44 families, 11 subfamilies, 1 tribe, 34 genus) in site 2 (Baraghan, upstream of Kordan stream), and 111 ( 7 classes, 18 orders, 44 families, 10 subfamilies, 1 tribe, 31 genus) in site 3 (downstream of Kordan). Therefore, richness was greatest at site 2, and lowest at site 3. The most ubiquitous taxa included Ephemeroptera (Epeorus, Rhithrogena, Baetis and Cloeon) Plecoptera (Chloroperla), Trichoptera (Hydropsychidae), and Diptera (Athericidae, Simuliidae, Tabanidae). Density was also highest at site 2 with 3216 ind. $\mathrm{m}^{-2}$, and lowest at site 3 with 2050 ind. $\mathrm{m}^{-2}$ (Table 3).

The scores calculated for Family - level Biotic Index (FBI) were lowest (4.67) and rated good water quality at site 1 (some organic pollution probable). The scores at sites 2 and 3 were 5.04 and 5.24 and rated fair (fairly substantial pollution likely) (Table 4).

The value calculated for EPT Richness at site 1 was 8, "under a little perturbation", for sites 2 and 3 were 9 and 7 respectively, also "under a little perturbation". However, the number of families in orders Ephemeroptera, Plecoptera, and Trichoptera (EPT Richness) was not significantly different among sites during the study.

\section{Discussion}

A timely review of empirical studies, conducted on the biodiversity of stream insects, was published by Vinson and Hawkins (1998). In the summary of this review, it was generally found that physical complexity promoted biological richness. Kordan Stream with stony bedrock, low stream order and high elevation is located in the temperate zone and a mountainous region. The mean annual temperature shows that this is a region with cold winters and mild summers. This has favored a suitable condition for the macro invertebrates.

According to nutrients measured during this study, Kordan stream is classified as oligo-mesotrophic stream (Smith et al., 2006). Although the water quality of the downstream site was lower than that of upstream sites, but the pollution level as a whole was not considerable and this stream could be regarded as a rather clean and healthy environment.

\subsection{Macroinvertebrate communities}

A total of 142 macroinvertebrate taxa distributed across 1 superphylum, 4 phyla, 3 subphyla, 9 classes (Insecta, Oligochaeta, Arachnida, Gastropoda, and Crustacea, Pelecypoda, Collembola and Hirudinea), 21 orders, 56 families, 11 subfamilies, 1 tribe and 38 genera were collected from the sampled sites during the time of study. Samples were dominated by insects and yielded 10 order, 42 families and 11 subfamilies with a density of 34500 ind. $\mathrm{m}^{-2}$. Dipterans with 13 families, Coleopterian with 7 families and Ephemeroptera, Plecoptera and Trichoptera every one with 5 families were composed the most richness. It seems that differential abundance and high richness in Kordan stream is due to naturally-occurring variations in hydrological and ecological properties such as low stream order (Crunkilton and Duchrow, 1991; Grubaugh et al., 1996), proper velocity (in the range of 30 to $120 \mathrm{~cm} . \mathrm{s}^{-1}$ ) (Beauger et al., 2006) and flow condition (Nelson and Lieberman, 2002; Wood et al., 2005).

During the study period, the lowest values of richness were observed in May, high-water period, and the highest was observed in March and October, low water period. During low water period, the habitats are more stable and time for macroinvertebrate colonization is longer allowing the increment of the species richness and abundance (Principle et al., 2007). Moreover, in Kordan Stream, insect abundance patterns were seasonal and the difference 
in the number of individuals between the months was significant $(\mathrm{p}<0.05)$. For example, emergence of mayflies (Ephemeroptera, Baetidae) was observed during winter or some dragonflies and damselflies had explosive emergence during April and May, and then soon disappeared. In general, flood regime would influence the temporal patterns of macroinvertebrate communities by decreasing total number of invertebrates (Merritt and Cummins, 1996; Gonzalez et al., 2003; Baraille et al., 2005), or exerts a great influence on the stream-dwelling invertebrate communities (Baptista et al. 2001).

Regarding the number of taxa collected over the annual period and from two upstream sites 1 and 2, site 2 with 121 taxa showed the highest number. Density was also highest at site 2 with 3216 ind. $\mathrm{m}^{-2}$, and lowest at site 3 with 2050 ind. $\mathrm{m}^{-2}$. This may be due to the presence of larger amounts of microhabitat in confined area and more stable condition at this sampling site (Bass, 1995; Nelson and Lieberman, 2002). Trichopteran insects were the most frequent order at site 2 because of appropriate substrates (rocky substrate, large amount of woody debris) for development of periphyton (and aufwuchs) in this site. Plecoptera, Coleoptera and Diptera were also abundant in this site for adequate sources of coarse particulate organic matter (tall trees in riparian zone) (Rohasliney and Jackson, 2007). Also large woody debris entrap the allochthonous organic material and forming leaf packs as attachment sites for most benthic macroinvertebrate colonization (Vanderwel et al., 2006).

Site 1 and 3 were more similar, just at site 3, dominance of gatherers (mainly chironomids) and high frequency of Oligochaeta, Arachnida and Gastropoda may be interpreted as a cumulative rural sewage and runoff agricultural activities (Cao et al., 1997). However, It was found that there were not significant differences in the number of taxa and number of individuals between upstream sites and downstream (One-way ANOVA, $\mathrm{p}>0.05$ ).

During the study period, Family-level biotic index score for site 1 was 4.67 which indicate "Good" water quality with some organic pollution probable. The scores calculated for sites 2 and 3 were 5.04 and 5.45 rated "Fair" with "fairly substantial pollution likely "(Hilsenhoff, 1988). Furthermore, during the study period, clear differences in FBI scores were not observed among stations ( $p>0.05)$.

EPT Richness value at site one was 8, "under a little perturbation". Sites 2 and 3 were also "under a little perturbation" with scores 9 and 7, respectively (Bode, 1993). The number of families in orders Ephemeroptera, Plecoptera, and Trichoptera (EPT Richness) was not significantly different among sites during the study period. However, in Kordan Stream, species richness was generally high, insects were much more prevalent than Oligochaetes and pollution-intolerant taxa were present throughout the study period at all sites, indicating high water and habitat quality.

Evidence generated by this study indicates that anthropogenic activities has not resulted in negative impacts to benthic macroinvertebrate assemblages in the Kordan stream and this stream be considered to be in good condition environmentally in all stations (from a water quality perspective according to HFBI values) as well as in terms of their stream biota (i.e., benthic macroinvertebrate assemblage composition and EPT richness), and the environmental conditions and habitat specifications play a major rule in the high richness and distribution of these organisms. Although at present biological integrity of this stream in terms of species richness (and productivity) is relatively intact and it is in generally in good condition, downstream part of it is going to be influenced by non point perturbations such as stressful condition, habitat degradation, deforestation and construction. Finally, based on its faunal assemblages, if this stream is protected from pollution and other ecological risk factors then it could serve as an ecological diversity unit in the area and serve as a good baseline for future comparisons. This situation emphasizes the importance of formulating and implementing a management program regarding the control of human activities development in the future, of course within a framework of an integrated management plan for the whole of its sub-river basin.

\section{References}

Allan, J.D. \& Flecker, A.S. (1993). Biodiversity conservation in running waters. Journal of Bioscience. 43, $32-43$.

Baptista, D.F., Buss, D.F., Dorville, F.M. \& Nessimian, J.L. (2001). Diversity and habitat preference of aquatic insects along the longitudinal gradient of the Macae River basin, Rio de Janeiro, Brazil. Journal of Revista Brasileira de Biologia, 61(2), 249-258.

Barbour, M.T., Gerritsen, J., Snyder, B.D. \& Stribling, J.B. (Eds.) (1999). Rapid Bioassessment Protocols for Use in Streams and Wadeable Rivers: Periphyton, Benthic, Macroinvertebrates and Fish, Second Edition EPA 841-B-99-002 U. S. Environmental Protection Agency, Office of Water, Washington, D.C.

Bass, D. (1995). Species Composition of Aquatic Macroinvertebrates and Environmental Condition in Cucumber Creek. Proceedings of the Oklahoma Academy of Science, 75, 39-44. 
Beauger, A., Lair, N., Reyes-Marchant, P. \& Peiry, J.L. (2006). The distribution of macroinvertebrates assemblage in a reach of the River Allier (France), in relation to riverbed characteristic. Journal of Hydrobiologia, 571, 63-76.

Bode, R.W., Novak M.A. \& Abele, L.E. (1991). Methods for rapid biological assessment of Streams. NYS Department of Environmental Conservation Technical Report.

Bode, R.W. (1993). 20 years trends in water quality of rivers and streams in New York State, based on macroinvertebrate data, 1972-1992. New York State Department of Environmental Conservation Technical Report.

Cao, Y., Bark, A.W. \& Williams, W.P. (1996). Measuring the responses of macroinvertebrate communities to water pollution: a comparison of multivariate approaches, biotic and diversity indices. Journal of Hydrobiologia, 341, 1-19.

Cobb, D.G., Galloway, T.D. \& Flannagon, J.F. (1992). Effects of discharge and substrate stability on density and species composition of stream insects. Canadian Journal of Fisheries and Aquatic Sciences, 49, 1788-1795.

Crunkilton, R.L. \& Duchrow, R.W. (1991). Use of stream order and biological indices to assess water quality in the Osage and Black River basins of Missouri. Journal of Hydrobiologia, 224, 155-156.

Davis, W.S., T.P. \& Simon (1995). Biological assessment and criteria: tools for water resource planning and decision making. Lewis Publishers, CRC Press, Roca Raton, Florida.

Federal Interagency Stream Restoration Working Group (2001). Stream Corridor Restoration: Principles,

Processes, and Practices. Part 653 of the National Engineering Handbook. USDA-Natural Resources

Conservation Service.

Fenoglio, S., Guido, B. \& Francesca, B. (2002). Benthic macroinvertebrate communities as indicators of river environment quality: an experience in Nicaragua. Journal of Revista de Biologia Tropical, 50(3/4), 1125-1131.

Fore, S., Karr, J.R. \& Wissemen, R.W. (1996). Assessing invertebrate responses to human activities: Evaluating alternative approach, Journal of North American Benthological Society, 15(2), 212-231.

Gonzalez, J.M., Basaguren, A. \& Pezo, J. (2003). Macroinvertebrate communities along a third-order Iberian Stream. Annales de Limnologie-International Journal of Limnology, 39(4), 287-296.

Greenberg, A.E., Clesceri, L.S. \& Eaton, A.D (Eds.), 1992. Standard Methods for the examination of water and wastewater, American Public Health Association, Washington. D.C.

Griffith, M.B., Husby, P., Hall, R.K., Kauffman, P.R. \& Hill, B.H. (2002). Analysis of macroinvertebrate assemblage in relation to environmental gradients among lotic habitats of California's Central Valley. Journal of Environmental monitoring and Assessment, 82(3), 281-309.

Grubaugh, J.W., Wallace, J.B. \& Houston, E.S. (1996). Longitudinal changes of macroinvertebrate communities along an Appalachian stream continuum. Canadian Journal of Fisheries and Aquatic Sciences, 53(4), 896-909.

Hilsenhoff, W.L. (1988) Rapid field assessment of organic pollution with a family-level biotic index. Journal of North American Benthological Society, 7(1), 65-68.

Hu, T.J., Wang, H.W. \& Lee, H.Y. (2007). Assessment of environmental condition of Nan-Shih Stream in Taiwan. Journal of Ecological Indicators, 7, 430-441.

Karr, J.R. (1981). Assessment of biotic integrity using fish communities. Journal of Fisheries, 6(6), 21-27.

Karr, J.R. \& Chu, W.E. (1999). Restoring life in running waters. Island Press, Washington D.C.

Malmqvist, B. and Rundle, S. (2002), Threats to running waters ecosystems of the world. Journal of Environmental Conservation, 29(2), 134-153.

McCafferty, W.P. (1981). Aquatic Entomology, Jones \& Bartlett Publishers, Boston.

Merritt, R.W. \& Cummins, K.W. (1996). An Introduction to the Aquatic Insects of North America ( $3^{\text {rd }}$ edition). Kendell/Hunt Publishing Company, Iowa.

Nelson, S.M. \& Lieberman, D.M. (2002). The influence of flow and other environmental factors on benthic invertebrates in the Sacramento River, U. S. A. Journal of Hydrobiologia, 489(1-3), 117-129.

Ohio, E.P.A. (1987). Biological criteria for the protection of aquatic life, volume2: users manual for biological field assessment of Ohio surface waters. Division of Water Quality Monitoring and assessment, Surface Water Section, Ohio Environmental Protection Agency, Columbus. 
Plafkin, J.L., Barbour, M.T., Porter, K.D., Gross, S.K. \& Hughes, R.M (1989). Rapid bioassessment protocols for use in Streams and Rivers: Benthic macroinvertebrate and Fish. U. S. Environmental Protection Agency Office of Water EPA/444/4-89-001 Washington D.C.

Principle, R.E., Raffaini, G.B., Gualdoni, C.M., Oberto, A.M. \& Corigliano, M.C (2007). Do hydraulic units define macroinvertebrate assemblage in mountain streams of central Argentina? Journal of Limnologia, 37, 232-236.

Rohasliney, H. \& Jackson, D.C. (2007). Lignite mining and Stream canalization influences on aquatic macroinvertebrate assemblages along the Natchez Trace Parkway, Mississippi, USA. Journal of Hydrobiologia, 598, 149-162.

Rosenberg, D.M. \& Resh, V.H. (1996). Freshwater Biomonitoring and Benthic Macroinvertebrates. Chapman \& Hall, New York.

Shieh, S.H. \& Yang, P.S. (2000). Community Structure and Functional Organization of Aquatic Insects in Agricultural Mountain Stream of Taiwan. Journal of Zoological Studies, 39(3), 191-202.

Smith, A.J., Bode, R.W. \& Kleppel, G.S. (2007), A nutrient biotic index (NBI) for use with benthic macroinvertebrate communities. Journal of Ecological Indicators, 7, 371-386.

Suozzo, k. (2006). The use of aquatic insects and benthic macroinvertebrate communities to assess water quality upstream and downstream of the village of Stamford wastewater treatment facility. [Online] Available: SUNY Oneonta biology candidate enrolled in Biol. 644-Topics in Entomology.

Vanderwel, M.C., Malcom, J.R., Smith, S.M. \& Nurul, I. (2006). Insect community composition and trophic guild structure in decaying logs from eastern Canadian pine-dominated forests. Journal of Forest Ecology and Management, 225 (1-3), 190-199.

Weigel, B.M. \& Robertson, D.M. (2007). Identifying Biotic Integrity and Water Chemistry Relations in Nonwadeable Rivers of Wisconsin: Toward the Development of nutrient Criteria. Journal of Environ. Manage, 40(4), 691-708.

Wood, P.J., Gunn, J., Smith, H. \& Abas-kutty, A. (2005). Flow permanence and macroinvertebrate community diversity within groundwater dominated headwater stream and springs. Journal of Hydrobiologia, 545, 55-64.

Younes-Baraille, Y., Garcia, X. and Gagneur, J. (2005). Impact of the longitudinal and seasonal changes of the water quality on the benthic macroinvertebrate assemblages of the Andorram Streams. Journal of Comptes

Rendus Biobgies, 328 (10-11), 963-976.

Table 1. Physico-chemical data in Kordan stream, February 2008- January 2009

\begin{tabular}{|c|c|c|c|c|c|c|c|c|c|c|c|c|}
\hline & 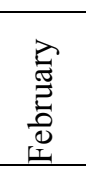 & $\begin{array}{l}\frac{\pi}{0} \\
\stackrel{\Xi}{\Sigma}\end{array}$ & $\overline{\vec{c}}$ & $\stackrel{\vec{\Sigma}}{\Sigma^{2}}$ & $\Xi$ & $\stackrel{\gtrsim}{\Xi}$ & 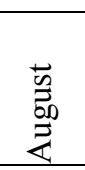 & 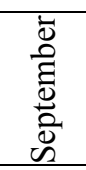 & $\begin{array}{l}\overline{0} \\
\stackrel{0}{0} \\
\stackrel{0}{0}\end{array}$ & $\begin{array}{l}\overline{\mathrm{D}} \\
\overrightarrow{0} \\
\overline{0} \\
\vec{z} \\
z\end{array}$ & $\begin{array}{l}\bar{\Xi} \\
\text { है } \\
\text { ठू. } \\
\stackrel{0}{0}\end{array}$ & 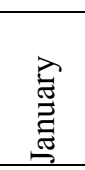 \\
\hline TEMP $\left({ }^{\circ} \mathrm{C}\right)$ & 6.86 & 12 & 12.6 & 14.0 & 17.7 & 18.7 & 15.6 & 15.3 & 11.56 & 5.6 & 4.33 & 4 \\
\hline $\mathrm{EC}\left(\mu \mathrm{s} . \mathrm{cm}^{-1}\right)$ & 323 & 396 & 263 & 256 & 327 & 324 & 417 & 401 & 391 & 354 & 366 & 350 \\
\hline $\mathrm{DO}\left(\mathrm{mg} \cdot \mathrm{l}^{-1}\right)$ & 11.9 & 10.9 & 10.7 & 10.1 & 9.44 & 9.3 & 10 & 10 & 11.5 & 11.7 & 11.8 & 11.9 \\
\hline $\mathrm{BOD}_{5}\left(\mathrm{mg} . \mathrm{l}^{-1}\right)$ & 1.69 & 1.72 & 1.43 & 1.27 & 2 & 2.17 & 2.9 & 2.42 & 2.11 & 2.03 & 1.53 & 1.05 \\
\hline $\mathrm{pH}$ & 8 & 8 & 8 & 8 & 8 & 8 & 8 & 8 & 8 & 7.5 & 7.5 & 7.5 \\
\hline $\mathrm{NO}_{3}-\mathrm{N}\left(\mathrm{mg} . \mathrm{l}^{-1}\right)$ & 25 & 27 & 18 & 17 & 13 & 12 & 11 & 11 & 15 & 18 & 19 & 21 \\
\hline $\mathrm{NO}_{3}-\mathrm{N}\left(\mathrm{mg} . \mathrm{l}^{-1}\right)$ & 0.6 & 0.56 & 0.37 & 0.42 & 0.56 & 0.26 & 0.28 & 0.31 & 0.45 & 0.56 & 0.52 & 0.56 \\
\hline
\end{tabular}


Table 2. Physico-chemical data from Kordan stream, $\mathrm{St}=\mathrm{Station}$

\begin{tabular}{|l|l|l|l|}
\hline & St1 & St2 & St3 \\
\hline TEMP $\left({ }^{\circ} \mathrm{C}\right)$ & $11.53 \pm 4.48$ & $11.63 \pm 4.96$ & $11.7 \pm 5.65$ \\
\hline EC $\left(\mu \mathrm{s} . \mathrm{cm}^{-1}\right)$ & $313 \pm 76.02$ & $343 \pm 49.35$ & $347 \pm 44.04$ \\
\hline $\mathrm{DO}\left(\mathrm{mg} . \mathrm{l}^{-1}\right)$ & $11 \pm 0.87$ & $10.86 \pm 0.77$ & $10.58 \pm 0.62$ \\
\hline $\mathrm{BOD}_{5}\left(\mathrm{mg} . \mathrm{l}^{-1}\right)$ & $1.12 \pm 0.49$ & $1.56 \pm 0.38$ & $2.1 \pm 0.71$ \\
\hline $\mathrm{pH}$ & $7.8 \pm 0.31$ & $7.8 \pm 0.31$ & $7.8 \pm 0.31$ \\
\hline $\mathrm{PO}_{4}\left(\mathrm{mg} . .^{-1}\right)$ & $0.016 \pm 0.002$ & $0.016 \pm 0.004$ & $0.018 \pm 0.005$ \\
\hline $\mathrm{NO}_{3}\left(\mathrm{mg} . \mathrm{l}^{-1}\right)$ & $0.47 \pm 0.15$ & $0.45 \pm 0.16$ & $0.51 \pm 0.21$ \\
\hline
\end{tabular}

Table 3. Taxonomic composition and abundances of macroinvertebrates collected from all sites in Kordan Stream, February 2008- January 2009.

\begin{tabular}{|c|c|c|c|c|c|}
\hline Family & Subfamily & Genus & $\bar{n}$ & 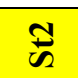 & $\frac{m}{n}$ \\
\hline \multirow{2}{*}{ Baetidae } & & Baetis & 644 & 655 & 522 \\
\hline & & Cloeon & 489 & 689 & 78 \\
\hline \multirow{2}{*}{ Heptageniidae } & & Epeorus & 33 & 100 & 78 \\
\hline & & Rhithrogena & 11 & - & 11 \\
\hline Caeniidae & & Caenis & - & 11 & - \\
\hline Leptophlebiidae & & Paraleptophlebia & 11 & 11 & 11 \\
\hline Oligoneuriidae & & & 33 & 56 & 11 \\
\hline Capniidae & & Capnia & 22 & 22 & 22 \\
\hline Chloroperlidae & & Chloroperla & 22 & 22 & 22 \\
\hline \multirow{2}{*}{ Perlodidae } & \multirow{2}{*}{ Isoperlinae } & Isoperla & 11 & 11 & - \\
\hline & & Isogenoides & 178 & 644 & 33 \\
\hline \multirow{2}{*}{ Perlidae } & Acroneuriinae & & 11 & 55 & 11 \\
\hline & Perlinae & & 11 & 33 & 67 \\
\hline Leuctridae & & Leuctra & 22 & 278 & 11 \\
\hline Hydropsychidae & & & 11 & - & - \\
\hline \multirow{2}{*}{ Brachycentridae } & & Oligoplectrum & 11 & 11 & 11 \\
\hline & & Micrasema & 11 & 11 & 11 \\
\hline Hydroptilidae & & Ochrotrichia & 11 & 22 & 11 \\
\hline Glossosomatidae & Glossosomatinae & & 56 & 11 & 11 \\
\hline Polycentropodidae & & & 11 & 0 & -- \\
\hline Coenagrionidae & & Argia & 11 & 11 & 11 \\
\hline Aeshnidae & & Aeshna & 11 & 11 & 11 \\
\hline Athericidae & & Atherix & 11 & 22 & 11 \\
\hline Blephariceridae & & Bibiocephala & 56 & 11 & 11 \\
\hline \multirow{7}{*}{ Chironomidae } & & & 410 & 710 & 810 \\
\hline & Diamesinae* & & 11 & 11 & 11 \\
\hline & Orthocladinae* & & 22 & 22 & 33 \\
\hline & Chironominae* & $<$ Tanytarsini $>$ & 22 & 22 & 33 \\
\hline & Tanypodinae* & & 11 & 11 & 11 \\
\hline & Telmatogetoninae* & & 11 & 11 & - \\
\hline & Simuliinae & & 267 & 189 & 44 \\
\hline Psychodidae & & Telmatoscopus & 11 & 11 & 11 \\
\hline \multirow{2}{*}{ Empididae } & & Chelifera & 11 & 11 & 11 \\
\hline & & Hemerodromia & 11 & 11 & 11 \\
\hline Dixidae & & Dixa & 11 & 11 & 11 \\
\hline Stratiomyidae & & Euparyphus & 11 & 11 & 11 \\
\hline Tabanidae & & & 11 & 11 & 11 \\
\hline \multirow{2}{*}{ Tipulidae } & & Tipula & 11 & 11 & 11 \\
\hline & Limoniinae & Antocha & 11 & - & - \\
\hline Culicidae & & & 11 & 11 & 11 \\
\hline Ceratopogonidae & & & - & 11 & 11 \\
\hline
\end{tabular}




\begin{tabular}{|c|c|c|c|c|c|} 
Dolichopodidae & & & - & - & 11 \\
\hline \multirow{2}{*}{ Elmidae } & & Elmis & 33 & 22 & 11 \\
\hline Gyrinidae & & Phanocerus & 22 & 11 & 11 \\
\hline Helodidae & & Dineutus & 11 & 22 & 11 \\
\hline Hydrophilidae & Scirtes & 11 & 11 & - \\
\hline Hydroscaphidae & & Laccobius & 11 & 11 & 11 \\
\hline Hydraenidae & & Hydraena & - & 11 & - \\
\hline Curculionidae & & & 11 & - & - \\
\hline Hebridae & & & - & 11 & - \\
\hline Aphididae & & & 11 & 11 & - \\
\hline Pyralidae & & & 11 & 11 & 11 \\
\hline Braconidae & & & 11 & 11 & - \\
\hline Sisyridae & & Isotomurus & - & 11 & - \\
\hline Isotomidae & & Gammarus & 11 & 11 & 11 \\
\hline Gammaridae & & Physa & - & 11 & 11 \\
\hline Physidae & & Valvata & 11 & - & - \\
\hline Limaeidae & & Potamopyrgus & - & 11 & 11 \\
\hline Valvatidae & & Pisidium & - & 11 & 11 \\
\hline Hydrobiidae & & & 11 & 11 & 22 \\
\hline Sphaeridae & & & - & 11 & 11 \\
\hline Lumbricidae & & & - & - & 11 \\
\hline Lumbriculidae & & & - & 11 & 11 \\
\hline Glossiphonidae & & & 11 & 11 & 11 \\
\hline Planariidae & & & 11 & 11 & 11 \\
\hline Pisauridae & & & 2416 & 3216 & 2061 \\
\hline Thomisidae & & & & \\
\hline Hygrobatoidea & & & & 11 \\
\hline & ind.-2 & & & & 11 \\
\hline
\end{tabular}

(* identified from nymph, $>$ : tribe)

Table 4. HFBI and EPT Richness values at different sites in Kordan stream, February 2008- January 2009.

\begin{tabular}{|c|c|c|c|c|c|c|c|c|c|c|c|c|c|c|}
\hline & & Feb & Mar & April & May & June & July & Aug & Sep & Oct. & Nov & Dec & Jan & Ave \\
\hline \multirow{3}{*}{$\overline{\underline{I}}$} & St1 & 5.43 & 5.36 & 4.92 & 4.67 & 5.47 & 5.39 & 5.3 & 4.83 & 3.9 & 3.82 & 2.23 & 4.98 & \begin{tabular}{|l}
4.67 \\
\end{tabular} \\
\hline & St2 & 5.86 & 5.67 & 5.58 & 4.94 & 5.43 & 5.53 & 5.58 & 4.94 & 4.55 & 4.43 & 2.89 & 5.15 & 5.04 \\
\hline & St3 & 5.9 & 5.72 & 5.61 & 5.36 & 5.48 & 5.67 & 5.72 & 5.23 & 5.11 & 4.65 & 3.19 & 5.28 & 5.24 \\
\hline \multirow{3}{*}{ 实 } & St1 & 4 & 7 & 5 & 5 & 6 & 7 & 7 & 9 & 10 & 11 & 8 & 13 & 8 \\
\hline & St2 & 9 & 8 & 5 & 4 & 8 & 9 & 6 & 10 & 12 & 10 & 11 & 10 & 9 \\
\hline & St3 & 6 & 7 & 5 & 3 & 5 & 5 & 7 & 7 & 9 & 9 & 8 & 10 & 7 \\
\hline
\end{tabular}

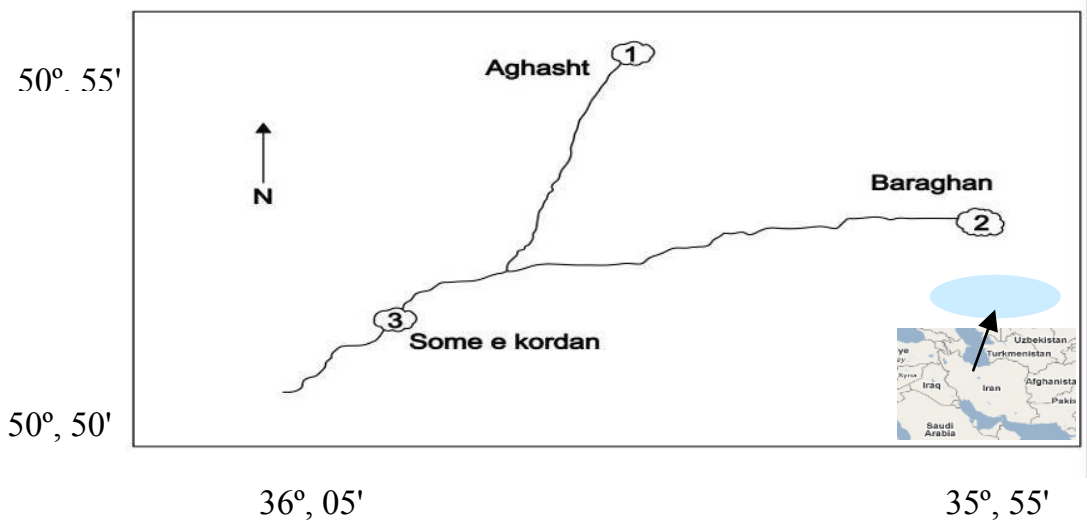

Figure 1. Schematic map of Kordan Stream and location of stations (not to scale). 